\title{
POTENSI PEMBELAJARAN MANUSIA : PERSPEKTIF NEUROSAINS DAN ISLAM.
}

\begin{abstract}
HIMAYATUL IZZATI
Guru PAI SDN 2 Kembang Kerang Kecamatan Aikmel Lotim

Absract

The verses of the Al-Quran which talk about the potential of learning and neuroscience, describe the activity of the mind and the brain as a learning instrument to understand, study and analyze, these signals can be traced through key terminology related to human brain activity. The terms tafakkur, tadabbur, ta'aqqul are theological foundations that describe the potential for human learning in a Neouroscience perspective. The brain is the center of human intelligence which controls the entire nervous system in capturing learning activities. with the power of the human brain can find various things that can facilitate human life. Cues of potential learning by maximizing brain nerve function (Neuroscience) can be traced to, QS Asy-Shams Verses 7-9, QS. An-Nahl 78, QS Ar-Rum 8, QS Al-Baqarah 219 and QS. Muhammad 24. The potential for human learning that is implemented in Islamic education, must develop a variety of potentials, so that the implementation of Islamic education can maximize the development of a comprehensive potential, such as Tarbiyah Imaniyah, Khuluqiyah, Tarbiyah, Jismiyah, Tarbiyah Aqliyah, Nafsiyah Ijtima'iyah. By maximizing the development of the potential, it will produce quality Islamic education output.
\end{abstract}

Keywords: Potential, Islamic Educational Learning Neurosciences

\section{A. Latar Belakang.}

Al-Qur'an diturun untuk ummat manusia, sehingga menjadi tidak aneh, ketika Al-Qur'an menjadikan manusia sebagai pusat pembahasan dalam setiap ayat-ayatnya, tidak terkecuali juga persoalan potensi manusia dalam pembelajaran dengan segala perspektif, baik itu filsafat, sosiologi, antropologi ataupun Neurosains ${ }^{1}$, yang belakangan ini ramai diperbincangkan oleh psikolog atau pun pakar neuron.

Otak merupakan organ manusia yang maha penting, otak menentukan kualitas hidup seseorang, dengn fungsinya yang sangat komplek telah menempatkan otak sebagai sarana yang penting dalam kehidupan seseorang terutama dalam kegiatan pembelajaran untuk mengembangkan potensinya. Dengan kekuatan otak mansuia dapat menemukan berbagai

\footnotetext{
${ }^{1}$ Neurosains secara etimologis merupakan ilmu Neuron yang mempelajari system Syaraf atau sel -sela Syaraf dengan pendekatan multidispliner sedangkan secara Terminologi, Neurosains, merupakan ilmu yang mengkaji tentang system Syaraf dengan dasar ini Neurosains disebut juga sebagai ilmu yang mempelajari otak dan seluruh fungsi Syaraf belakang. Lebih jelas lihat. Taufik Pasiak, Tuhan dalam Otak Manusia meujudkan Kesalehan spiritual berlandaskan Neurosains, (Bandung: Mizan,2012),132.
} 
hal, mulai pada tingkat molekuler atau atom, pengobatan berbagai penyakit, penemuan tekologi canggih hingga menembus tata surya. ${ }^{2}$

Potensi manusia sebagai mahluk pembelajar akan berekembang dengan baik, apabila dilakukan dengan melibatkan beberapa potensi lainnya, seperti potensi akal, pendengaran dan penglihatan secara bersamaan. Di samping itu faktor eksternal semisal lingkungan pendidikan yang memberikan ruang ekspresi yang seluas luasnya untuk pengembangan potensi aqliyah akan memberikan andil terhadap percepatan penguatan potensi yang melekat pada manusia.

Manusia sebagai mahluk potensial, memiliki beragam potensi yang dapat dikembangkan, mulai dari potensi Biologis (Basyariah), potensi Intlektual (aqliyah), potensi Sosial, dan potensi Spritual (ruhaniyah). Tergantung pada sikap setiap manusia, untuk mengembangkan potensi yang dimiliki ${ }^{3}$. Isyarat-Isyarat Al-Qur'an tentang pengembangan potensi manusia, sebagaimana yang dijelaskan dalam. QS Asy-Syams Ayat 7-9.

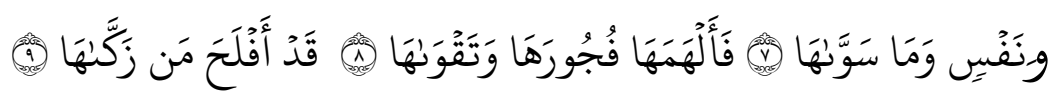

Artinya: Dan jiwa serta penyempurnaannya (ciptaannya). Maka Allah mengilhamkan kepada jiwa itu (jalan) kefasikan dan ketakwaannya. Sesungguhnya, beruntunglah orang-orang yang mensucikan jiwa itu" (QS. AsSyams: (91): 7-9).

Dalam tafsir Al Misbah menjelaskan, bahwa Ayat di atas menjelaskan agar manusia mampu menangkap makna yang baik dan buruk, manusia diberikan pilihan untuk melakukan kebaikan atau keburukan. ${ }^{4}$ Potensi kebaikan dan keburukan yang melekat pada setiap manusia, harus mampu diarahkan, Dalam konteks ini, pola pendidikan Islam yang berperan untuk mengarahkan dan mengembangkan nilai-nilai kebaikan pada manusia agar menjadi pribadi yang barakhlak mulia.

Manusia sebagai mahluk pembelajar, untuk membantu potensi akal (aql) sehingga bisa bekerja secara maksimal dalam mengembangkan potensinya, Allah memberikan potensi lainnya, seperti panca indera, hati (qalb), pendengaran (sama'), dan penglihatan (bashar).

\footnotetext{
${ }^{2}$ Taruna Ikrar, Ilmu Neurosains Modern (Yogyakarta:Pustaka Pelajar,2015),3.

${ }^{3}$.Jamil Abdul Aziz, Potensi Manusia dalam Perspektif Al-Qur'an dan Psikologi Behaviorisme dan Humanisme serta Implikasinya dalam Pendidikan, Jurnal Qiro'ah, Vol 10.No1. 2020.

${ }^{4}$ M. Qurais Shihab, Tafsir-Al Misbah, Jilid 15, (Jakarta:Lentera Hati,2006),286
} 
Dengan bantuan potensi inilah diharapkan mampu mengoptimalkan potensi akal $(a q l)$ untuk memahami ilmu pengetahuan dan teknologi. Semua potensi tersebut diberikan kepada manusia dengan tujuan untuk mengetahui kebenaran (al-haq), untuk mengetahui kebenaran tersebut diperlukan cara berfikir yang benar. Dengan mengoptimalkan potensi diri untuk senantiasa, bertafakkur ${ }^{5}$, tadabbur $^{6}$, dan ta'aqul ${ }^{7}$.

Secara khusus ilmu yang mengkaji tentang otak dan akal manusia disebut dengan Neourosains ${ }^{8}$. Kajian tentang Neurosains di Indonesia mengalami lompatan kualitatif, seiring dengan perkembangan ilmu pengetahuan dan teknologi yang semakin maju. Kajian ini dapat diimplementasikan dalam berbagai disiplin keilmuan termasuk juga pendidikan islam. Semangat integrasi dan interkoneksi keilmuan di lingkungan perguruan tinggi islam, semakin memperluas kajian tentang Neourosains ${ }^{9}$ kemudian diintegrasikan dengan kosepsi pendidikan islam.

Akal merupakan salah satu bagian terpenting yang melekat dalam diri manusia, dan akal pula yang membedakan manusia dengan mahluk ciptaan tuhan lainnya. Akal sering dihubungkan dengan otak ${ }^{10}$. Otak jangan dilihat sebagai sebuah entitas tunggal. Mengkaji otak haruslah dengan memahaminya sebagai sekumpulan komponen yang satu sama lain

\footnotetext{
${ }^{5}$ Tafakkur merupakan aplikasi akal untuk membuat analisa dan sintesa melalui alat indra (penglihatan, pendengaran, penciuman, dan perasaan). Lebih jelas Lihat Abu Muhammad Iqbal, Pemikikran Pendidikan Islam (Yogyakarta: Pustaka Pelajar, 2015), 536.

${ }^{6}$ Taddabur merupakan adalah memikirkan makna dibalik yang tersurat,atau bisa disebut juga memikirkan yang tersirat dibalik yang tersurat (Lihat Baharudin, Aktualisasi Psikologi Islami (Yogyakarta: Pustaka Pelajar, 2011),75.

${ }^{7}$ Kata ta'aqqul ditinjau dari segi kebahasaan memiliki beberapa makna, secara leksikal kata ta'aqqul berasal dari kata 'aqala yang memiliki makna berfikir. Kata 'aqala dalam bentuk kata kerja (fi'l) berarti habasa yang berarti mengikat. Orang yang mengikat akalnya disebut dengan aqil atau orang yang dapat mengikat hawa nafsu atau dengan kata lain ta'aqqul merujuk kepada mengendalikan sesuatu, baik berupa lisan, pikiran, maupun perbuatan, . Lihat Mohammad Ismail, Konsep Berfikir dalam Al-Qur'an dan Implikasinya Terhadap Pendidikan Akhlak, 301) .

${ }^{8}$ Taufik Pasiak, Manajmen Kecerdasan : Memberdayakan IQ,EQ dan SQ untuk Kesuksesan hidup (Bandung:Mizan,2006),46

${ }^{9}$ Pentingnya peran Neurosains dalam kehidupan manusia, sehingga perlu upaya untuk menumbuhkan kesadaran masyarakat akan pentingnya Neurosains untuk pengembangan pembelajaran dilingkungan pendidikan. Pemetaan dalam networking antara sel syaraf di otak dalam menjalankan fungsinya, seperti, fungsi berfikir,fungsi kordinasi, fungsi regulasi terhadap berbagai organ tubuh lainnya, termasuk fungsi leadearshif. Jika pemetaan terhadap system neurosains dapat dituntaskan maka dampak penemuan tersebut, akan berpengaruh sangat luar biasa terhadap kehidupan ummat manusia di masa yanag akan datang. Taruna Ikrar, Ilmu Neurosains Modern,(Yogyakarata: Pustaka pelajar, 2019), 216

${ }^{10}$ Secara psikologis, Otak Merupakan Sistem syaraf pusat yang berfungsi untuk mengontrol seluruh aktivitas kehidupan manusia. Sebagai system syaraf pusat otak memiliki peran sentral untuk mengatur dan mengendalikan fungsi gerkan Tubuh, serta memiliki volume sekitar, $1.350 \mathrm{cc}$ selain itu di dalam otaak manusia terdapat 100 juta sel Neuron sehingga otak manusia dapat berfungsi sesuai dengan perannya masing masing. Lebih jelas Lihat. Taruna Ikrar, Ilmu Neurosains ,..85.
} 
saling berhubungan, sehingga mekanisme kerja yang saling berkaitan. Selainn memiliki hubungan yang sangat erat dengan spiritualitas dan religiusitas juga memiliki potensi rasionalitas (akal). Kedua potensi ini harus mampu dimaksimalkan secara simultan dalam pembelajaran Pendidikan islam. Pembelajaran sebagai sebuah aktivitas "pengetahuan" tentu membutuhkan keterlibatan otak dan akal sebagai basis penguatan ilmu pengetahuan. Disinilah letak urgensi Neurosains sebagai sebuah instrument untuk penguatan keilmuan Islam dalam rangka membentuk manusia yang kreatif dan inovatif dalm mengembangkan potensi pembelajaran manusia.

Otak memiliki keterbatasan sedangkan akal berkerja lebih jauh untuk memperoleh pengetahuam sesuai dengan kekuatan potensi yang telah dikembangkan, akal memperoleh pengetahuan yang tak terbatas akibat rangsangan Indra, bahkan dia bisa melampaui kegunaanya ${ }^{11}$.

Di dalam Al-Qur'an terminologi tadabbur (merenung), tafakkur(berfikir) dan ta'aqul (berakal) dan Tabashur (memahami) menunjukkan aktivitas otak dan akal (aql) dalam kesehariannya, untuk melejitkan potensi pembelajaran pada setiap manusia. Dengan demikian pendidikan islam harus berorientasi pada pengembangan potensi akal sekaligus membentuk manusia yang kritis serta kreatif yang dilandasi ahlakul karimah.

Dengan demikian tulisan ini akan mencoba mengelaborasi tentang potensi pemeblajaran manusia dengan sudut pandang Neourosains dan agama, belajar sebagai sebuah aktivitas intlektual dengan melibatkan akal seutuhnya untuk melakukan eksplorasi ayat-ayat qauliyah dan Qauniyah. Melibatkan akal dan otak (neurosains) yang dibaluti dengan nilai-niali keislaman, untuk memaksimalkan potensi manusia dalam aktivitas pembelajaran. Pembelajaran yang dibangun berbais pada kekuatan Neurosains dan Spritualitas keislaman, akan melahirkan manusia yang memiliki pengetahuan yang terintegratif dan tidak kering dengan nilai spritualitas. Paradigma Neurosains dan Agama dalam bingkai Potensi pembelajaran akan diejawantahkan dalam bentuk pemahaman untuk di implementasikan dalam praksis kehidupan.

\section{B. Potensi Pembelajaran Manusia.}

\footnotetext{
${ }^{11}$ Lukman Hakim Fuad, Peran akal Menurut Pandangan al-Gazali, Jurnal Substantia 15.No1,2013, 81.
} 
Potensi merupakan kemampuan atau kekuatan diri seseorang baik yang belum terwujud maupun yang telah terwujud, akan tetapi belum sepenuhnya terlihat ${ }^{12}$. Sedangkan menurut Kamus Besar Bahasa Indonesia (KBBI), potensi merupakan kemampuan yang mempunyai kemungkinan untuk dikembangkan; kekuatan; kesanggupan; daya ${ }^{13}$. Berdasarkan pemaknaan ini, Potensi pembelajaran manusia adalah suatu metode yang digunakan untuk memaksimalkan potensi pikiran atau akal manusia dengan menggunakan otak kanan dan otak kirinya secara simultan dalam kegiatan pembelajaran. Akal memiliki peranan penting dalam konstruksi pembelajaran, kemajuan ilmu pengetahuan dan teknologi yang begitu massif dewasa ini, tidak bisa dilepaskan dari optimalisasi potensi akal manusia dalam setiap denyut peradaban manusia. Disinilah tarbiyatul aqliyah memegang peranan penting dalam pendidikan Islam.

Secara terminologi potensi merupakan citra asli yang dinamis yang terdapat dalam diri manusia dan dapat diaktualisasikan dalam bentuk tingkahlaku. Dimana citra tersebut sudah ada sejak awal penciptaannya. ${ }^{14}$ Secara aktual, potensi pembelajaran manusia akan mengalami lompatan kualititaf, ketika potensi tersebut dapat dikembangkan sesuai dengan bakat dan minat masing-masing.

Di dalam islam potensi akal menempati posisi yang sangat penting, kualitas seseorang akan diukur sejauh mana dia mampu memfungsikan akalnya dalam kehidupan sehari-hari. Ketika akal seseorang tidak mampu berfungsi dengan baik (gangguan kejwaan), dia bisa dibebaskan dari ketentuan hukum agama yang berlaku.

Akal merupakan merupakan Instrumen rohaniyah yang dapat digunakan untuk mengingat, menganalisis, menyimpulkan dan membedakan antara yang baik dan buruk, sehingga dapat memperkuat keimanan dan ketakwaan kepada allah SWT. Dengan akal manusia dapat menerima ilmu pengetahuan baru yang digunakan untuk berpikir secara

\footnotetext{
${ }^{12}$ Wikipedia, 10 November 2020

${ }^{13}$ Kamus Besar berbahasa Indonesia (KBBI), aplikasi Online, 10 November 2020

${ }^{14}$ Rohmalina Wahab, Psikologi Agama (Jakarta: PT Raja Grapindo Persada,2015),26
} 
mendalam agar dapat menemukan sesuatu yang berguna untuk menyelesaikan berbagai persoalan hidup yang dihadapi oleh manusia. ${ }^{15}$

Ayat-ayat Al-Qur'an yang menggembarkan tentang potensi pembelajaran Manusia terdapat QS. 16:78 :

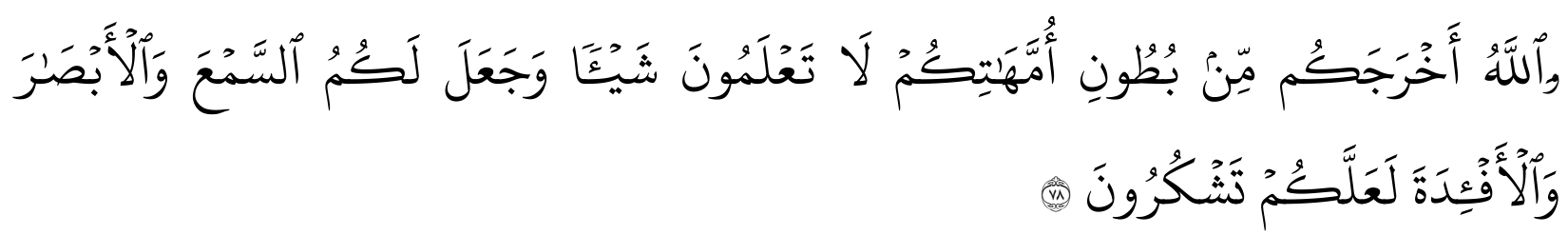

Artinya: Dan Allah mengeluarkan kamu dari perut ibumu dalam keadaan tidak mengetahui sesuatupun, dan Dia memberi kamu pendengaran, penglihatan dan hati, agar kamu bersyukur. (An- Nahl 78).

Berdasrkan ayat di atas, bahwa manusia dilahirkan dalam kondisi tidak mengetahui apa apa, manusia sebagai pembelajar diberikan potensi yang melekat pada dirinya sehingga dengan berbagai potensi yang diberikan manusia akan belajar. Potensi pembelajaran pada manusia dalam meliputi aspek fisik (jasmani) yakni pendengaran dan penglihatan serta aspek psikis yakni akal. Mendengar adalah menangkap bunyi-bunyi (suara) dengan indera pendengaran. Kolaborasi antara akal, pendengaran dan penglihatan dalam aktivitas pembelajaran akan memberikan rangsangan dan stimulus kepada otot syaraf otak yang kemudian dicerna oleh akal untuk dijadikan sebagai sebuah ilmu pengetuan.

Manusia dan potensi pembelajaran merupakan dua entitas yang tak dapat dipisahkan, dia bersemayam dalam jasad bersamaan dengan kelahiraan manusia. Potensinya pembelajaran manusia akan muncul seiring dengan perkembangan potensi akal, pendegaran dan penglihatan mengalami proses kehidupan di dunia. Pemtaangan potensi tersebut dilakukan lewat lemabaga pendidikan islam ataupun lembaga pendidikan lainnya yang akan menjadi pemicu sekaligus pemacu kebangkitan potensi aqliyah manusia. Pada titik ini teori lawas ibnu Sina menemukan momentumnya, bahwa tugas utama pendidikan islam adalah menggali dan mengembang potensi akal peserta didik.

\footnotetext{
${ }^{15}$ Ahmad Miftahul Huda, otak dan akal dalam kajian Al-Qur'an dan Neurosains, Jurnal Pendidikan Islam Indonesia, Volume 5, Nomor 1, Oktober 2020.
} 
Pembelajaran merupakan kewajiban bagi setiap muslim, dan kewajiban tersebut tidak akan berjalan tanpa melibatkan akal ${ }^{16}$, akal merupakan instrument paling utama dalam kegiatan pembelajaran. Akal memiliki posisi yang sangat vital dalam segala sendi kehidupan, tanpa akal manusia akan kehilangan hakikat kemanusiaanya, sehingga sangat beralasan ketika agama mengajarkan kita untuk menjaga lima hal ${ }^{17}$ termasuk akal, untuk kehormatan dan harmonisasi kehidupan manusia sebagai mahluk pembelajar

\section{Potensi Pembelajaran dalam Perspektif Neurosains dan Islam}

Ibnu Khaldun pernah berujar bahwa setiap manusia memiliki kelebihan yang diberikan oleh Allah SWT. yaitu berupa akal. Oleh karena itu manusia mendapatkan posisi yang lebih tinggi dan sempurna apabila dibandingkan dengan makhluk lainnya. ${ }^{18}$

Dalam perspektif Al-Qur'an, potensi pembelajaran yang ada dalam diri manusia tidak bisa dipisahkan dengan akal. Aktivitas berfikir hendaknya mampu mengilhami kepada kepada pengutan nalar akan makna eksitensi Allah SWT sebagai pencipta alam semesta dan Isinya.

Dalam konstruksi model pendidikan islam dewasa ini, belum maksimal dalam menggunkan potensi otak untuk memecahkan berbagai persoalan ataupun melahirkan gagasan baru. Penyebabnya karena system pendidikan kita lebih fokus pada pengembangan potensi otak kiri (Logika, kata-kata,matemaatika, obyektif, analitis dan holistik), sementara otak kanan kurang mendapat porsi yang sesuai untuk dikembangkan (Imajinasi,music gambar, Subyektif, relasional dan Analogi). Ketidak seimbangan pengembangan potensi otak dalam pendidikan islam telah melahirkan ketimpangan dalam menyerap ilmu pengetahuan. Menjadi sangat penting, memdadukan antara otak kiri dan kanan untuk dioptimalkan serta di aplikasikan secara efektif dalam system pendidikan Islam.

Potensi pembelajaran manusia yang diaplikasikan dalam pendidikan islam, setidaknya harus menerapkan beberapa hal, sehingga dalam penyelenggaraan pendidikan Islam dapat memaksimalkan potensi secara komprehensif, :

a. Tarbiyah Imaniyah: Pembelajaran dalam Islam diarahkan untuk penanaman nilai-nilai keimanan disertai dengan penguatan aspek-aspek keimanan sehingga menjadi pondasi

\footnotetext{
${ }^{16}$ Hery Nur Aly, Ilmu Pendidikan Islam (Jakarta: Logos, 1999),2.

${ }^{17}$ Lima kebutuhn penting yang tetap harus dipelihara oleh setiap muslim, 1. Menjaga Agama, 2.Menjaga jiwa, 3. Menjaga akal, 4.Menjaga Keturunan, 5. Menjaga Harta atau biasa disebut dengan maqashid al-khamsah.

${ }^{18}$ Ibnu Khaldun, Muqaddimah (Jakarta: Pustaka Firdaus,2008), 241.
} 
spiritual bagi kehidupan seseorang ${ }^{19}$. Dalam realisasinya, pendidikan harus format pada pengokohan iman seseorang yang menjadi dasar dari segala pola pikir, sikap, dan perbuatan manusia.

b. Tarbiyah Khuluqiyah: Pembelajaran dalam Islam juga diarahkan sebagai sebuah proses pendidikan untuk menata kepribadian, akhlak, dan etika dalam kehidupan sehari-hari ${ }^{20}$. Dalam perluasannya, akhlak yang mulia merupakan salah satu output dari pendidikan Islam.

c. Tarbiyah Jismiyah: Tidak bisa dipungkiri bahwa jasmani yang sehat merupakan suatu keniscayaan bagi kelangsungan hidup manusia. Demikian halnya demi tegaknya agama dan peradaban Islam, umat Muslim harus memiliki fisik atau jasmani yang memberinya kekuatan dalam mengemban semangat syiar nilai-nilai Islam ${ }^{21}$.

d. Tarbiyah Aqliyah: Jasmani yang kuat tanpa disertai akal yang sehat hanya akan mereduksi nilai kemanusiaan karena peradaban manusia dibangun melalui eksplorasi dan kreasi akal budi manusia. ${ }^{22}$ Kemajuan ilmu pengetahuan dan teknologi tidak terlepas dari optimalisasi potensi intelektualitas manusia. Disinilah urgensi tarbiyah aqliyah dalam pendidikan Islam.

e. Tarbiyah Nafsiyah: Tarbiyah Nafsiyah di sini merujuk pada pendidikan jiwa atau lebih berkaitan dengan aspek-aspek mental yang dimiliki manusia. Kombinasi jasmani dan akal tidak akan lengkap tanpa disertai keberadaan mental yang kokoh atau jiwa yang stabil. $^{23}$

f. Tarbiyah Ijtima'iyah: Tarbiyah Ijtima'iyah diarahkan untuk melengkapi aspek dasar keberadaan manusia yang juga merupakan makhluk sosial. Pendidikan ini ditujukan untuk mewujudkan tatanan masyarakat yang bersendikan nilai-nilai sosial yang bersumber pada Al-Qur'an dan Hadits ${ }^{24}$.

${ }^{19}$ Hanna Djumhana Bastaman, Integrasi Psikologi dengan Islam: Menuju Psikologi Islami (Yogyakarta: Pustaka Pelajar,2011), 19.

\footnotetext{
${ }^{20}$ Hanna Djumhana Bastaman, Integrasi Psikologi dengan Islam: Menuju ....45

${ }^{21}$ Ramayulis, Psikologi Agama, (Jakarta: Kalam,2016),143.

${ }^{22}$ Mahmud Arif, Pendidikan Islam Transformatif, (Yogyakarta:LKiS,2008),27.

${ }^{23}$ Ahmad Farid, Tazkiyatun Nafs belajar membersihkan Hati, (Bandung:Taqiya,2015) 87.

${ }^{24}$ Abudin Nata, Filsfat Pendidikan Islam,(Jakarta:Gaya media Pratama,2008),79.
} 


\section{Ayat-Ayat Potensi Manusia \& Neurosains Dalam Al-qur'an}

Pengembangan potensi akal (neourosains) dalam Al-Qur'an memiliki landasan Normatif teologis di dalam Al-Qur'an. Ayat ayat tentang potensi akal (neurosains) dapat dilacak melalui terminologi kunci yang berhubungan dengan aktivitas otak manusa. Istilah-Istilah tafakkur, tadabbur, ta'aqul merupakan landasan teologis tentang ayat-ayat potensi pembelajaran manusia dalam perspektif Neourosains.

Perkembangan kajian potensi pembelajaran dengan sudut pandanag Neurosains semakin banyak diaktualisasikan dalam semua bidang keilmuan, di antaranya bidang psikologi pendidikan Islam. Pendekatan Neourosains, Menjadi kajian yang cukup menarik apabila kajian didekati dengan beragam perspektif dan keilmuan, termasuk dengan aspek Psikologi pendidikan Islam.

Dalam kajian Psikologi pendidikan Islam, selama ini belum dilakukan dengan serius pada wilayah kajian pembelajaran dalm sudut pandang neurosains, padahal pendidikan selalu menyangkut dengan optimalisasi potensi otak dan akal ${ }^{25}$. Belum seriusnya perhatian pendidikan Islam terhadap neurosains mengakibatkan pemahaman kita atas sistem multiple Intlegensi semakin parsial. Oleh karena itu perlu kiranya untuk dilakukan kajian mendalam tentang ayat-ayat yang berkaitan dengan aktivitas otak manusia, terutama ayat-ayat yang menyebutkan 'Aql .

Ayat -ayat Al-Qur'an tentang potensi pembelajaran dan Neurosains, pembahasannya disesuaikan dengan konteks literal teks yang terdapat dalam ayat tersebut. Ayat -ayat yang menggambarkan aktivitas akal dan otak sebagai Instrumen pembelajaran, sekaligus sebagai isyarat tentang ayat Neurosains dalam Al-Qur'an :

1. Surat Ar-Rum ayat 8.

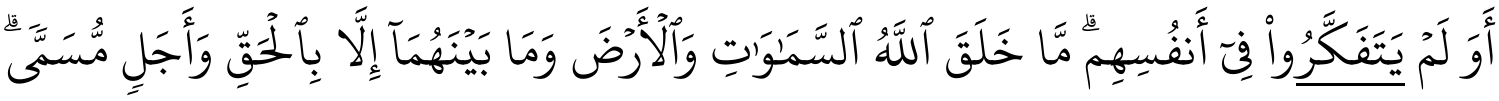
Artinya Dan mengapa mereka tidak memikirkan tentang (kejadian) diri mereka? Allah tidak menjadikan langit dan bumi dan apa yang ada diantara keduanya melainkan dengan (tujuan) yang benar dan waktu yang ditentukan QS Ar-Rum 8

\footnotetext{
${ }^{25}$ Suryadi. Pendidikan Islam Anak Usia Dini dalam perspektif Neurosains :Robotik Akademik dan Saintifik, Edukasia : Jurnal Penelitian Pendidikan Islam, 13 No.2.2018, 231.
} 
2. QS. Al-A'raf (7).184

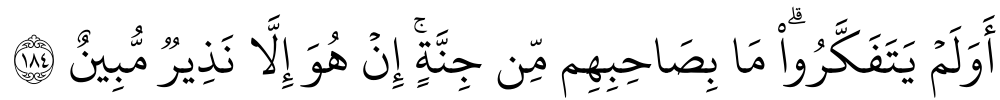

Artinya "Dan tidakkah mereka memikirkan bahwa teman mereka (Muhammad) tidak gila,

dia tidak lain hanyalah seorang pemberi peringatan lagi pemberi penjelas

QS Al-Baqarah (2) 219.

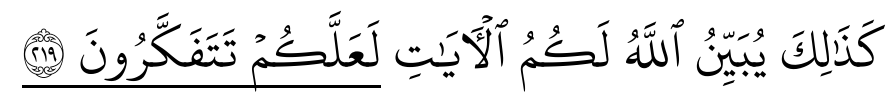

Artinya: demikianlah Allah menerangkan ayat-ayat-Nya kepada kalian aga kalian berfikir, ..." (QS. Al-Baqarah [2] : 219

3. Surat Muhammad 24.

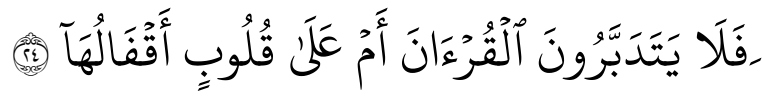

Artinya : Maka apakah mereka tidak memperhatikan Al Quran ataukah hati mereka Terkunci..?

Secara tersirat, Al-Qur'an memberikan perhatian yang sangat besar terhadap akal, agar dapat digunakan untuk memikirkan kebenaran dan kebaikan. Akal merupakan kekuatan potensial yang digunakan untuk memahamai ilmu pengetahuan, dan dengan ilmu pengetahuan manusia dapat menggapai kebahagiaan dunia dan akherat. Tidak berlebihan AlRagif Isfahani menyebutkan akal sebagai sebuah entitas yang paling penting dalam struktur tubuh manusia.

Hasil riset mendalam yang dilakukan oleh Faiz dan Suryadi terhadap ayat yang memberikan Isyarat tentang aktivitas akal, paling terdapat 49 ayat ${ }^{26}$ yang tersebar di beberapa surat. Persebaran ayat yang berbicara tentang akal dengan berbagai konteksnya, telah menunjukkan betapa pentingnya posisi akal dalam ajaran Islam. Kekuatan potensi akal

${ }^{26}$ Terdapat QS. al-Baqarah [2]: 44, 73, 75, 76, 164, 170, 171, 242; QS. Ali Imran [3]: 65, 118; QS. alMaidah [5]: 58, 103; QS. al-Anam [6]: 32, 151; QS. al-A'raf [7] 169; QS. al-Anfal [8]: 22; QS. Yunus [10]: 16, 42, 100; QS. Hud [11]: 51; QS. Yusuf [12] 2, 109; QS. al-Ra'd [13]: 4; QS. al-Nahl [16]: 12, 67; QS. al-Anbiya' [21]: 10, 67; QS. al-Hajj [22]: 46; QS. al-Mu'minun [23]: 80; QS. al-Nur [24]: 61; QS. al-Furqan [25]: 44; QS. al-Syura [26]: 28; QS. al-Qashash [28]: 60; QS. al-Ankabut [29]: 35, 43, 63; QS. al-Rum [30]: 24, 28; QS. Yasin [36]: 62, 68; QS. al-Saffat [57]: 17; QS. al-Hasyr [59]: 14; QS. al-Mulk [67]: 10. Lihat Muhammad Faiz dan Suyadi. Tafsir Ayat-Ayat Neourosains, Aql dalam al-qur'an dan Relevansinya terhadap Pengembangan berfikir Kritis dalam Pendidikan Islam. Jurnal At-Tibiyan. Jurnal Ilmu Al-Qur'an dan Tafsir Volume 5 No 1,Juni 2020.141. 
telah melahirkan berbagai model perkembangan sains dan teknologi untuk menopang kebutuhan manusia. Kemajuan ilmu pengetahuan dan teknologi sebagai hasil kreasi akal, telah memanjakan manusia dalam berbagai asfek kehidupan. Tidak ada satupun aktivitas pembelajaran yang tidak melibatkan akal, bagi kelompok pengusung rasionalitas akal dijadikan sebagai satu satu alat untuk memburu kebenaran.

\section{E. Potensi Pembelajaran \& Neurosains Terhadap pengembangan Nalar Kritis Pendidikan Islam.}

Berbicara potensi pembelajaran tidak bisa dilepaskan dari Neurosains, keduanya saling bersimbiosis untuk merekonstruksi pengetahuan agar bisa sampai pada kebenaran tertinggi, yang dalam terminologi Mulla Sadra disebut dengan al-Mut'aaliyah. Menurut Mulla Sadra potensi pembelajaran manusia meliputi Pertama: panca indra, kedua, Indara Batin, (ingatan, berfikir, khayal), ketiga, akal dan qalbu. ${ }^{27}$ Penggabungan potensi qalbu dan akal dalam pencarian sebuah kebenaran ilmu, pada titik puncak akan melahirkan insan Kamil.

Akal merupakan sesuatu yang esensial bagi manusia, seluruh aktivitas pembelajaran harus diorientasikan pada pengaktipan nalar kritis peserta didik. Dengan demikian hasil pembelajaran diarahkan untuk membentuk manusia yang unggul, sehingga mampu berinovasi dan berpikir kritis terhadap berbagai persoalan yang dihadapi. Pada sisi yang potensi pembelajaran diarahkan untuk membentuk manusia yang berahlakul karimah secara social serta bertakwa kepada tuhan yang maha esa.

Misi utama pembelajaran, untuk transmisi ilmu pengetahuan dari satu generasi ke generasi berikutnya. Dan juga Aktivitas pembelajaran untuk mengaktualisasi potensi-potensi yang dimiliki oleh setiap individu menjadi kemampuan actual. Aktualisasi ragam potensi, yang secara psikologis dapat diklasifikasikan menjadi potensi akal, hati dan jiwa yang diarahkan untuk pembentukan dan peningkatan kualifikasi kemanusiaan.

Optimalisasi potensi akal dan Indra bisa menjadikan seseorang memiliki pengetahuan tentang realitas disekelilingnya sehingga dapat menuntunya untuk sampai pada pengetahaun. Kalau dikorelasikan dengan cara pandang ibnu Hizam maka pengetahuan itu diperoleh lewat

\footnotetext{
${ }^{27}$ Aksin Wijaya, Satu Islam Ragam Epistimologi dari Epistimologi Teosentris Ke Antroposentrimse (Yogyakarta:Pustaka pelajar,2014),136.
} 
verifikasi empirik, Indrawi, dan rasio yang berbasis pada penalaran rasional. ${ }^{28}$ Hal sel senada juga semapt di dilontarkan oleh Ilmuan Muslim Al-Kindi, ketika mendefinisikan Filsafat sebagai pengetahuan tentang hakekat sesuatu sesuai dengan kemampuan indrawi dan daya rasionalitas. ${ }^{29}$ Apresiasi yang tinggi terhadap daya indrawi dan Rasio membawa konsekuensi pada pengakuan akan pentingnya penalaran dalam pendidikan Islam.

Dalam kelompok rasionalitas, akal tidak hanya untuk mengetahui sesuatu, tetapi juga berfungsi untuk merumuskan terhadap benar salah dan baik buruknya sesuatu. Selain itu juga pembelajaran dipahami sebagai aktivitas intraksi dan sosialisasi, dalam konteks sosial pembelajaran selalu berkorelasi dengan nilai dan norma social dan berorientasi pada tuntutan social ${ }^{30}$. dengan demikian aktivitas pembelajaran tiadak boleh berjarak dengan realitas social yang mengitarinya. Justru pembelajaran membangun kepekaan terhadap setiap denyut setiap perubahan dan perkembangan social budaya sehingga memperoleh legitimasi dan relevansi fungsional di tengah masyarakat yang terus berdialektika.

Model pendidikan kritis, pernah dirumuskan dan dikembangkan oleh kelompok Ikhwan As-shafa, yang dalam konstruksi gagasan pendidikan sangat syarat dengan nuansa rekonstruksi social, sikap kritis dan transformatif . paradigma kritis inilah yang membawa kelompok Ikhwan As Shafa pada gerakan pencerahan pada masyarakat, sehingga masyarakat paham akan hak dan kewajajibannya, dan tidak lagi bertahan pada "budaya bisu". Pembinaan moral sosial menjadi tujuan utama pendidikan kritis Ihwan Al-Shafa.

\section{F. Kesimpulan}

Berdasarkan elaborasi di atas, Manusia dan potensi pembelajaran merupakan dua entitas yang tak dapat dipisahkan, dia bersemayam dalam jasad bersamaan dengan kelahiraan manusia. Potensinya pembelajaran manusia akan muncul seiring dengan perkembangan potensi akal, pendegaran dan penglihatan mengalami proses kehidupan di dunia. Pemtangan potensi tersebut dilakukan lewat lemabaga pendidikan islam ataupun lembaga pendidikan lainnya yang akan menjadi pemicu sekaligus pemacu kebangkitan potensi aqliyah manusia.

\footnotetext{
${ }^{28}$ Zainuddin dkk, Pendidikan Islam dari paradigma klasik hingga Kontemporer, (Malang:UIN Malang Press,2009),305.

${ }^{29}$ Imam Bernadib, Filsafat Pendidikan system dan Metode (Yogyakarta: Andi offset,1988),78

${ }^{30}$ Mehdi Nakosten, Kontribusi Islam atas Dunia Intlektual Barat Deskripsi Analisis Abad Keemasan Islam (Surabaya: Risalah Gusti,2003)257
} 
Pada titik ini teori lawas ibnu Sina menemukan momentumnya, bahwa tugas utama pendidikan islam adalah menggali dan mengembang potensi akal peserta didik.

Terdapat banyak Isyarat di dalam Al-Qur'an yang menjelaskan tentang Aktivitas Akal, ayat Al-Qur'an yang tentang akal bisa di temuai pada terminology yang menyebutkan aktivitas otak (Neourosain) semisal, Tadabbur, tafakkkur, dan ta'aqqul. Secara khusus kajian tentang akal dan otak manusia disebut dengan neurosains. Secara psikologis neurosains implementasikan dalam berbagai bidang keilmuan. Akan menjadi sangat menarik ketika Neurosains diinetgrasikan dalam kajian pendidikan islam.

Akal merupakan instrument rohaniah yang melakat pada manusia yang dapat mengingat menganalsis menyimpulkan dan membedakan antara yang baik dan buruk. Dengan demikian potensi pembelajaran harus berorientasi pada maksimalisasi pada aktivitas akal, sehingga pembelajaran mampu menghasilkan manusia yang unggul, memahami realitas kehidupan yang dasari oleh semangat keimanan dan ahlkul karimah.

Disamping itu potensi pembelajaran diarahkan untuk penguatan model pemikiran deduktif-empirik, sehingga pendidikan islam mampu berpikir kritis terhadap persoalan disekelilingnya, sebagaimana paradigma pendidikan islam ala Ikhwan Al-Shafa.

\section{G. Refrensi.}

Abdul Aziz Jamil, Potensi Manusia dalam Perspektif Al-Qur'an dan Psikologi Behaviorisme 10.No1. 2020.

Abudin Nata, Filsfat Pendidikan Islam,Jakarta:Gaya media Pratama,2008.

Ahmad Farid, Tazkiyatun Nafs belajar membersihkan Hati, Bandung:Taqiya,2015

Baharudin, Aktualisasi Psikologi Islami, Yogyakarta: Pustaka Pelajar, 2011.

Bastaman Hanna Djumhana, Integrasi Psikologi dengan Islam: Menuju Psikologi dengan Islami Yogyakarta :Pustaka Pelajar,2011.

Bernadib, Imam. Filsafat Pendidikan system dan Metode, Yogyakarta: Andi offset,1988. Hery Nur Aly, Ilmu Pendidikan Islam,Jakarta: Logos,1999.

Iqbal, Abu Muhammad Pemikikran Pendidikan Islam, Yogyakarta: Pustaka Pelajar, 2015

Ikrar, Taruna, Ilmu Neurosains Modern, Yogyakarata: Pustaka pelajar, 2019.

Kamus Besar berbahasa Indonesia (KBBI), aplikasi Online,

Khaldun, Ibnu, Muqaddimah, Jakarta: Pustaka Firdaus,2008..

Mahmud Arif, Pendidikan Islam Transformatif, Yogyakarta:LKiS,2008.

Nakosten, Mehdi, Kontribusi Islam atas Dunia Intlektual Barat Deskripsi Analisis Abad Keemasan Islam, Surabaya: Risalah Gusti,2003.

Pasiak Taufik, Tuhan dalam Otak Manusia meujudkan Kesalehan spiritual berlandaskan 
Neurosains, Bandung: Mizan,2012.

Pasiak, Taufik, Manajmen Kecerdasan : Memberdayakan IQ,EQ dan SQ untuk Kesuksesan hidup, Bandung:Mizan,2006.

Ramayulis, Psikologi Agama, Jakarta: Kalam,2016..

Shihab, M. Qurais Tafsir-Al Misbah, Jilid 15, Jakarta:Lentera Hati,2006.

Suryadi. Pendidikan Islam Anak Usia Dini dalam perspektif Neurosains :Robotik Akademik dan Wahab, Rohmalina, Psikologi Agama, Jakarta: PT Raja Grapindo Persada,2015.

Wijaya,Aksin, Satu Islam Ragam Epistimologi dari Epistimologi Teosentris Ke Yogyakarta: Pustaka Pelajar,2011.

Zainuddin dkk, Pendidikan Islam dari paradigma klasik hingga Kontemporer,Malang:UIN Malang Press,2009. 